\title{
A study on the direct effect of anthropogenic aerosols on near surface air temperature over Southeastern Europe during summer 2000 based on regional climate modeling
}

\author{
P. Zanis \\ Department of Meteorology and Climatology, School of Geology, Aristotle University of Thessaloniki, Greece
}

Received: 17 June 2009 - Revised: 17 September 2009 - Accepted: 10 October 2009 - Published: 21 October 2009

\begin{abstract}
In the present work it is investigated the direct shortwave effect of anthropogenic aerosols on the near surface temperature over Southeastern Europe and the atmospheric circulation during summer 2000. In summer 2000, a severe heat-wave and droughts affected many countries in the Balkans. The study is based on two yearly simulations with and without the aerosol feedback of the regional climate model RegCM3 coupled with a simplified aerosol model. The surface radiative forcing associated with the anthropogenic aerosols is negative throughout the European domain with the more negative values in Central and Central-eastern Europe. A basic pattern of the aerosol induced changes in air temperature at the lower troposphere is a decrease over Southeastern Europe and the Balkan Peninsula (up to about $1.2^{\circ} \mathrm{C}$ ) thus weakening the pattern of the climatic temperature anomalies of summer 2000. The aerosol induced changes in air temperature from the lower troposphere to upper troposphere are not correlated with the respective pattern of the surface radiative forcing implying the complexity of the mechanisms linking the aerosol radiative forcing with the induced atmospheric changes through dynamical feedbacks of aerosols on atmospheric circulation. Investigation of the aerosol induced changes in the circulation indicates a southward shift of the subtropical jet stream playing a dominant role for the decrease in near surface air temperature over Southeastern Europe and the Balkan Peninsula. The southward shift of the jet exit region over the Balkan Peninsula causes a relative increase of the upward motion at the northern flank of the jet exit region, a relative increase of clouds, less solar radiation absorbed at the surface and hence relative cooler air temperatures in the lower troposphere between $45^{\circ} \mathrm{N}$ and $50^{\circ} \mathrm{N}$. The southward extension of the lower troposphere aerosol induced negative temper-
\end{abstract}

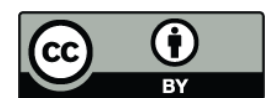

Correspondence to: P. Zanis (zanis@geo.auth.gr) ature changes in the latitudinal band $35^{\circ} \mathrm{N}-45^{\circ} \mathrm{N}$ over the Balkan Peninsula is justified from the prevailing northerly flow advecting the relatively cooler air from the latitudinal band $45^{\circ} \mathrm{N}-50^{\circ} \mathrm{N}$ towards the lower latitudes. The present regional climate modeling study indicates the important role of anthropogenic aerosols for the regional climate and their dynamical feedback on atmospheric circulation.

Keywords. Atmospheric composition and structure (aerosols and particles) - Hydrology (Anthropogenic effects) - Meteorology and atmospheric dynamics (Synoptic-scale meteorology)

\section{Introduction}

Aerosol particles influence climate by modifying both the global energy balance through absorption and scattering of radiation (direct effects), as well as the reflectance and persistence of clouds and the development and occurrence of precipitation (indirect effects) (Hansen et al., 1997; Lohmann and Feichter, 2001; Ramanathan et al., 2001). Aerosols enhance scattering and absorption of solar radiation and also produce brighter clouds (enhancement of cloud albedo due to smaller droplets) with longer cloud lifetime (due to smaller droplets) that are less efficient at releasing precipitation (Ruckstuhl et al., 2008; Ramanathan and Feng, 2009). These in turn lead to large reductions in the amount of solar radiation reaching Earth's surface causing the so-called "solar dimming" effect (Wild et al., 2007). The total direct aerosol radiative forcing as derived from models and observations is estimated to be $-0.5 \pm 0.4 \mathrm{~W} \mathrm{~m}^{-2}$ in global scale (with a medium-low level of scientific understanding) while the radiative forcing due to the first indirect effect (cloud albedo effect or Twomey effect which is that more numerous smaller cloud particles reflect more solar radiation) is estimated to be $-0.7 \mathrm{~W} \mathrm{~m}^{-2}$ (ranging from -1.8 to $-0.3 \mathrm{~W} \mathrm{~m}^{-2}$ ) with a low

Published by Copernicus Publications on behalf of the European Geosciences Union. 
level of scientific understanding (IPCC, 2007). The second indirect effect (which is that smaller cloud particles decrease the precipitation efficiency that results in prolonging cloud lifetime) is estimated to be roughly as large as the Twomey effect (Lohmann and Feichter, 2005).

These aerosol induced changes of the earth's radiation budget (negative radiative forcing) cause changes in atmospheric thermal structure, changes in synoptic and regional circulation systems, suppression of rainfall and less efficient removal of pollutants (Ramanathan and Feng, 2009). However the radiative forcing of absorbing aerosols can be also positive with significant regional climate effects as black carbon can absorb radiation and heat the air (semi-direct effect) resulting in a positive radiative forcing that partly offsets aerosol scattering effects (Jacobson, 2001; Menon et al., 2002). Especially, the semi-direct effect could maximize the positive radiative forcing when the absorbing aerosols are located within the boundary layer (Johnson et al., 2004). However, Lohmann and Feichter (2001) concluded that the absorption of solar radiation by absorbing aerosols (black carbon) can decrease cloud cover and liquid water path locally, but the indirect aerosol effects of increasing cloud lifetime and cloud albedo dominate.

Aerosols have both natural sources such as desert dust lifting, sea spray, volcanic explosions, biogenic organic emissions and anthropogenic sources such as fossil fuel and biomass burning. The uncertainty in the radiative forcing of Earth's radiation budget by anthropogenic aerosols, which are present mainly in the lower troposphere, greatly exceeds that of all other forcing mechanisms combined (IPCC, 2001, 2007). Hence the study of the anthropogenic component is crucial in view of assessing the impact of human activities on climate and air quality. Aerosols of anthropogenic origin are mainly composed of sulphates, carbonaceous particles (black carbon and organic carbon), nitrates, ammonium and mineral dust of industrial origin (Ghan and Schwartz, 2007). Black carbon, sulfate, and organics play a major role in the solar dimming at the surface (e.g. IPCC, 2007). Increasing of man-made aerosols in the atmosphere over the 20th century has dimmed the solar radiation at the earth's surface (Stanhill and Cohen, 2001), while recent results indicate signs of solar brightening in Europe due to subsequent decreases in anthropogenic aerosol concentrations (Norris and Wild, 2007; Ruckstuhl et al., 2008).

In order to study the climate feedback of aerosols it is necessary to couple climate and chemistry/aerosol models. The interactive coupling of complex climate models and full chemistry schemes is still computationally too demanding and alternatively simplified chemistry modules have been developed to allow chemistry-climate studies (Solmon et al., 2006). This approach has been mainly applied for global models (e.g. Chung and Seinfeld, 2002; Reddy and Boucher, 2004; Kim et al., 2007). Because of the relatively short lifetime of the aerosols, their spatial distribution is inhomogeneous, basically determined by local sources, rapid chemical transformations, transport and removal processes. As a consequence the aerosol effects are especially important on regional scale. Furthermore the radiative forcing of aerosols at regional scale can be much larger than that of the 20th century rise in the greenhouse gas concentrations (Ramanathan et al., 2001). Regional climate models (RCMs) offer useful tools to assess the regional impacts of anthropogenic aerosols because of their relatively high-resolution, their detailed physical parameterisations and their suitable computational cost compared to global climate models (GCMs) and chemistry climate models (CCMs) (Solmon et al., 2006).

Relatively few studies have coupled simplified aerosol models to RCMs (e.g. Qian et al., 2001; Giorgi et al., 2002, 2003; Ekman and Rodhe, 2003; Zakey et al., 2006). For example, Giorgi et al. (2002) and Qian et al. (2003) found that the regional climatic direct and indirect effects of anthropogenic aerosols over East Asia can partially explain the cooling trend observed over various regions of China during the last decades of the 20th century. Konare et al. (2008) investigated the effect of the shortwave radiative forcing of Saharan dust on the West African monsoon using a RCM coupled to a dust model. Solmon et al. (2008) included in addition the climatic impact of the longwave radiative forcing of Saharan dust for the same region. Both studies reported a reduction of precipitation over the most of the Sahelian region in response to cooling over the Sahara and weakening of the West African monsoon intensity. Zhang et al. (2009) reported that the net surface radiative fluxes are decreased by the shortwave and longwave effects of dust aerosols at East Asia causing a surface cooling locally up to $-1^{\circ} \mathrm{C}$. Finally, Zakey et al. (2008) studied recently the radiative effects of sea-salt aerosols on regional climate for the first time using a RCM.

In the present work it is investigated the direct shortwave effect of anthropogenic aerosols on the near surface temperatures over Southeastern Europe and the atmospheric circulation during summer (from June to August) 2000 based on simulations performed by the regional climate model RegCM3 coupled with a simplified aerosol model.

\section{Data and methodology}

The regional climate model RegCM version 3 (Pal et al., 2007) was used for the regional climate simulations in this study. RegCM was originally developed at the National Center for Atmospheric Research (NCAR) and has been mostly applied to studies of regional climate and seasonal predictability around the world (Giorgi et al., 2006). The dynamical core is based on the hydrostatic version of the NCAR-PSU Mesoscale Model version 5 (MM5) (Grell et al., 1994). The radiative transfer package is taken from the Community Climate Model version 3 (CCM3) (Kiehl et al., 1996). The large-scale cloud and precipitation computations are performed by Subgrid Explicit Moisture Scheme 
(SUBEX; Pal et al., 2000). Ocean surface fluxes are computed according to the scheme of Zeng et al. (1998) and the land surface physics according to Biosphere-Atmosphere Transfer Scheme (BATS; Dickinson et al., 1993). The adopted convective scheme for the RCM simulations in this study is the Grell scheme (Grell, 1993) with the Fritsch and Chappell (1980) closure assumption.

The RegCM3/aerosol model is a coupled model between RegCM3 and a simplified anthropogenic aerosol model, which can be used to investigate the aerosol feedback to climate (Solmon et al., 2006). In this model version only the direct shortwave effects of anthropogenic aerosols are included. The aerosol model includes sulphur dioxide $\left(\mathrm{SO}_{2}\right)$, sulphate $\left(\mathrm{SO}_{4}^{=}\right)$, hydrophobic and hydrophilic carbonaceous particles such as black carbon (BC) and organic carbon (OC). Conversion of $\mathrm{SO}_{2}$ to $\mathrm{SO}_{4}^{=}$via both aqueous and gaseous phase chemical processes has been described by Qian et al. (2001). Because of its importance in removal processes, optical properties and cloud condensation nuclei formation, the hygroscopicity of carbonaceous particles is simply accounted by considering two states for BC and OC, hydrophobic and hydrophilic. Therefore a total of six tracers are taken into account by the aerosol model. $\mathrm{SO}_{2}$ emissions are provided by the public release of EDGAR (Emission Database for Global Atmospheric Research) global data base in one degree resolution over the globe. Briefly, this inventory accounts for fossil and bio -fuel combustions, industrial chemical production, biomass burning and waste treatment. The calculation of fossil fuel emissions for BC and OC particles is based on the Cooke et al. (2002) methodology and it accounts for different type of fuel combustions and emission factors. The inventory for $\mathrm{BC}$ and $\mathrm{OC}$ is provided in one degree resolution over the globe. The emission inventories adopted for this study are representative for the year 2000.

A recent evaluation study of RegCM3/aerosol model with ground-based measurements of $\mathrm{SO}_{2}$ from the EMEP European network as well as with aerosol optical depth measurements from ground based and satellite platforms revealed a consistent reproduction by the model of the observed spatial patterns (Solmon et al., 2006). Specifically, comparison with available AERONET (AErosol RObotic NETwork) AOD (Aerosol Optical Depth) values from ground-based remote sensing instruments revealed a satisfactory agreement within a factor of 1.5 between simulated and observed AOD over northern Europe in the visible and UV range for both summer and winter seasons of the year 2000. Furthermore comparison with the AOD values from satellite platforms with the MODIS (Moderate Resolution Imaging Spectroradiometer) instrument indicated that the position of AOD maxima is consistent between RegCM and MODIS results (Solmon et al., 2006). Nevertheless the MODIS AOD values found to be about two times larger than both the simulated and AERONET AOD values, especially over land for summer 2000 pointing to a significant uncertainty in the observations themselves (Solmon et al., 2006).
RegCM3/aerosol simulations were performed over a large European domain with a grid resolution of $50 \mathrm{~km} \times 50 \mathrm{~km}(18$ layers up to $50 \mathrm{hPa}$ ) forced by the NCEP-DOE AMIP-II Reanalysis dataset (Kanamitsu et al., 2002) for the year 2000. In order to investigate the impact of anthropogenic aerosol loading on air temperature and atmospheric circulation patterns, two full-year simulations were performed with a spin up time of 1 month; the control run (Crun) with the chemical tracers only being transported but having no feedback in the radiative scheme and one run including the direct aerosol feedback on the shortwave radiation (AFrun).

There are a number of limitations to be noted however for this study. First, the indirect aerosol effects in cloud properties are not taken into account in the simulations. According to IPCC (2007) the first indirect effect is comparable and can be larger than the direct aerosol effect in global scale but is more uncertain. The second indirect effect is estimated to be roughly as large as the first indirect effect but the uncertainties are even larger (Lohmann and Feichter, 2005).

The second limitation is that the direct effect of aerosols in longwave was also not taken into account in the simulations. However, the longwave direct radiative forcing is only substantial if the aerosol particles are large (such as dust or sea salt) and occur in considerable concentrations at higher altitudes, but this process is not significant for the smaller anthropogenic aerosols (IPCC, 2007; Ramanathan and Feng, 2009).

The third limitation is that the short length of the simulations presented in the study (one particular summer) is not sufficiently long to establish a climatic signal of the aerosol radiative forcing, but this study focuses on the short-term signals (a particular warm summer in Balkan Peninsula) rather than the long-term climate signals. An analysis of a 12-years simulation is in progress in order to establish a longer-term climate signal of the anthropogenic aerosols in Europe.

Another limitation of the study is the absence of natural emissions including biogenic particles, dust, sea-salt and forest fire particles which can contribute significantly for the atmospheric air composition of the Balkan Peninsula during summer. However the current study is focused solely on the effect of anthropogenic aerosols.

Finally another limitation is the fact that only the anthropogenic emissions within Europe are considered and hence the lateral boundaries are restricted in advection from outside. According to another study of this issue, limited area simulations are unable to provide reasonable assessment of the influence of large scale aerosol anomalies on the climate without a two way feedback interaction at the boundaries of the regional domain (Sud et al., 2009). 
a)

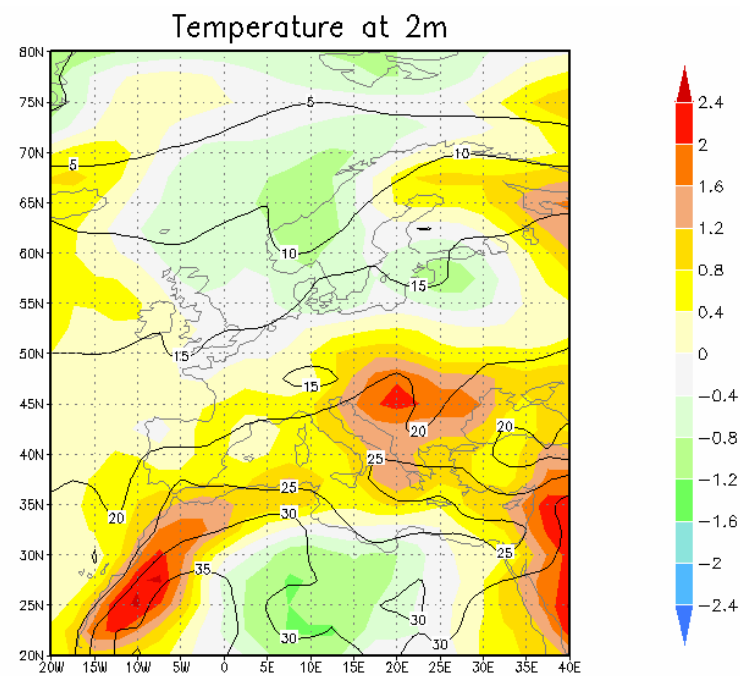

b)

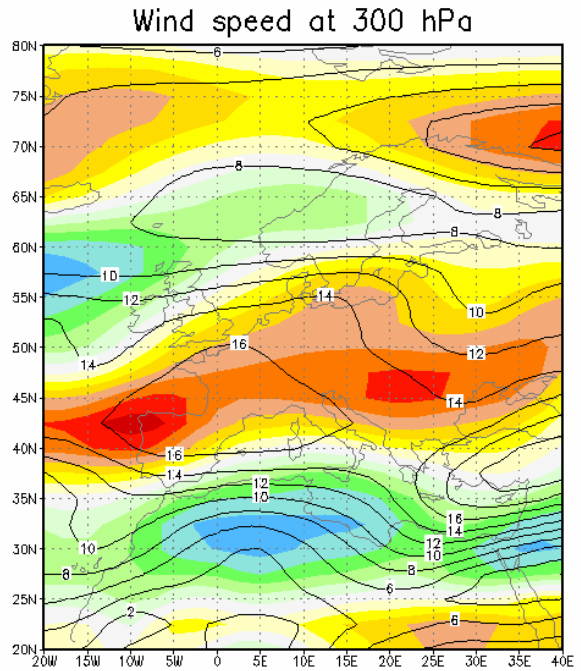

the highest temperature anomalies (in the range of 1 to $2^{\circ} \mathrm{C}$ ) are observed in Southeastern Europe (the Balkan Peninsula). Indeed, in summer 2000, a severe heat-wave and droughts affected many countries in the Balkans. According to the gridded distribution of temperature July 2000 anomalies with respect to 1961-1990 base period from the stations of the Global Historical Climatology Network Database, recordbreaking heat covered the Balkans and parts of the Middle East throughout much of the month, where average temperature anomalies exceeded $4^{\circ} \mathrm{C}$ (http://www.ncdc.noaa.gov/oa/ climate/research/2000/jul/global.html).

\subsection{Aerosol induced changes in air temperature}

The RegCM3/aerosol simulated mean fields in summer 2000 of the aerosol optical depth (AOD) at the visible due to the anthropogenic aerosols (carbonaceous particles and sulphates) indicate higher values in Central Europe extended to the Central Eastern Europe mainly in the latitudinal band between $48^{\circ} \mathrm{N}$ and $55^{\circ} \mathrm{N}$ (Fig. 2c). This spatial distribution of the anthropogenic aerosols is associated with: a) higher emissions in Central Europe as it can be seen in the fields of the EDGAR anthropogenic emissions of SO2 (Fig. 2a) and of black and organic carbon (Fig. 2b) and b) the transport of the emitted pollutants affected by the mean seasonal synoptic circulation with westerly flow above about $45^{\circ} \mathrm{N}$ (in central Europe) from the lower to upper troposphere and northwesterly flow over the Balkan Peninsula in the lower troposphere according to the RegCM3 simulated wind streamlines (see Fig. 3). The derived mean summer surface radiative forcing (sRF) field associated with the anthropogenic aerosol loadings is illustrated in Fig. $2 d$. The sRF is negative (as expected due to the solar dimming effect of anthropogenic aerosols) throughout the European domain with the more negative sRF values (less than $-60 \mathrm{~W} / \mathrm{m}^{2}$ at midday) in Central and Central-eastern Europe (in the latitudinal band $50^{\circ} \mathrm{N}-55^{\circ} \mathrm{N}$ ) where the highest anthropogenic aerosol loading is attained. It should be noted from Fig. 2 the spatial correlation between the AOD and sRF fields. For the larger part of Europe $\left(35^{\circ} \mathrm{N}-65^{\circ} \mathrm{N}\right.$ and $\left.0^{\circ} \mathrm{E}-40^{\circ} \mathrm{E}\right)$ it was calculated an average surface $\mathrm{RF}$ of $-16 \mathrm{~W} \mathrm{~m}^{-2}$ for a respective AOD value of 0.23 . Li et al. (2004) calculated due to Saharan dust aerosols RF values of $-35 \mathrm{~W} \mathrm{~m}^{-2}$ for AOD values between 0.8 and 1 consistent with observations. Konare et al. (2008) calculated with RegCM3 shortwave surface radiative forcing ranging from 0 to a maximum of about $-90 \mathrm{~W} \mathrm{~m}^{-2}$ over the area of maximum dust loading.

As it is illustrated in Fig. 4a, the radiative forcing of the anthropogenic aerosols affects the near surface air temperature distribution inducing significant changes ranging between -1.2 to $+1.2^{\circ} \mathrm{C}$. However, the pattern of the aerosol induced departures in air temperature of the lower and middle troposphere (Fig. 4) are not correlated with the respective pattern of the surface radiative forcing (Fig. 2b) indicating the complexity and the non-linearity of the mechanisms 

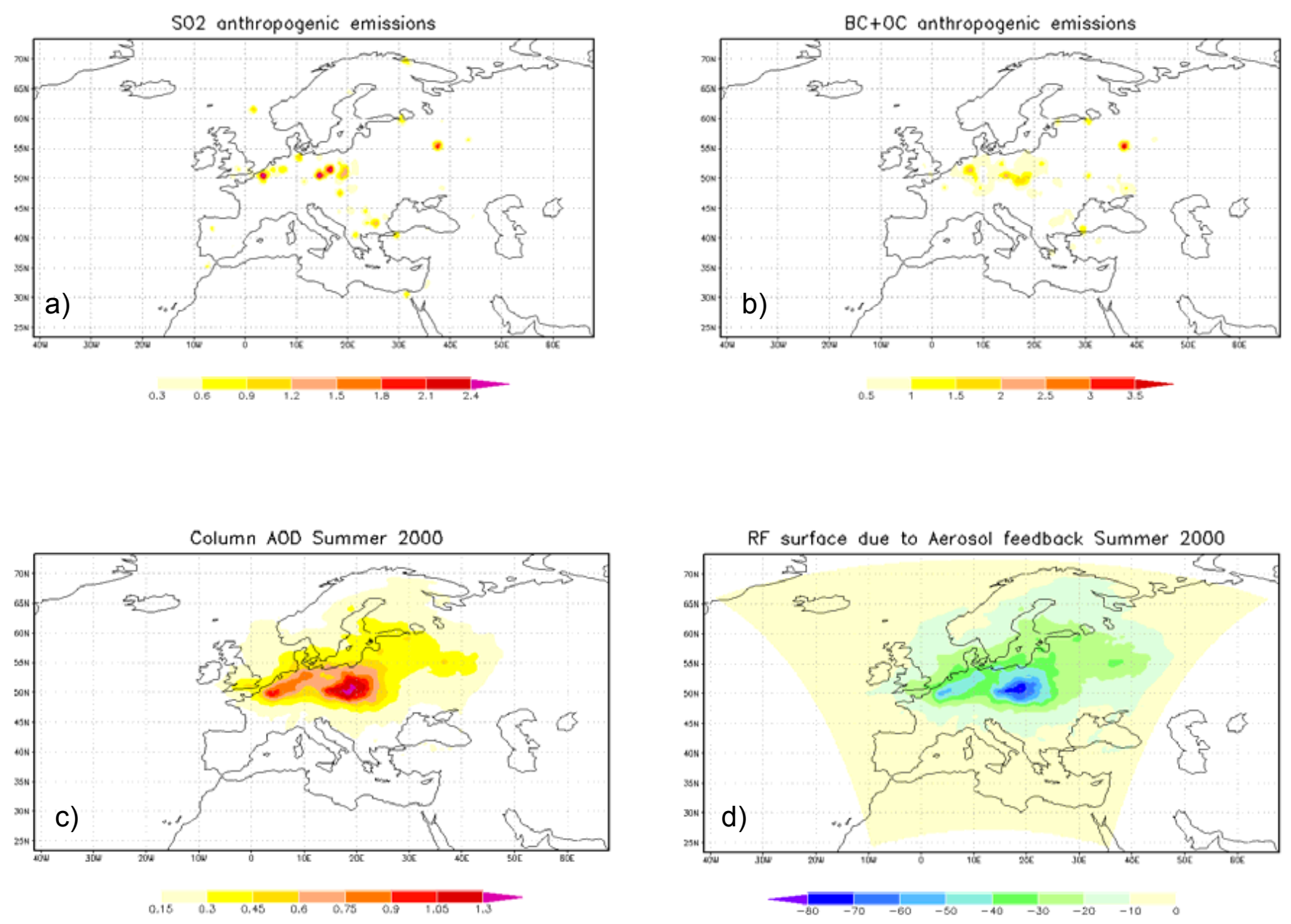

Fig. 2. Anthropogenic emission of (a) $\mathrm{SO}_{2}$ (in $10^{-9} \mathrm{~kg} \mathrm{~m}^{-2} \mathrm{~s}^{-1}$ ) and (b) the sum of black and organic carbon (in $10^{-12} \mathrm{~kg} \mathrm{~m}^{-2} \mathrm{~s}^{-1}$ ). Seasonal mean fields in summer of the year 2000 of (c) the aerosol optical depth and (d) the surface radiative forcing (in W/ $\mathrm{m}^{2}$ ) due to anthropogenic aerosols (carbonaceous particles and sulphates) obtained from the RegCM3/aerosol simulations.

linking the aerosol radiative forcing with the induced atmospheric changes.

The basic coherent structures of the aerosol induced changes in near surface air temperature (Fig. 4a) are a decrease of 0.8 to $1.2^{\circ} \mathrm{C}$ over Southeastern Europe and the Balkan Peninsula (between $20^{\circ} \mathrm{E}$ and $30^{\circ} \mathrm{E}$ ) and an increase of up to $1.2^{\circ} \mathrm{C}$ over the Northeastern Europe (between $30^{\circ} \mathrm{E}$ and $40^{\circ} \mathrm{E}$ ) resembling a dipole pattern. Mind that the aerosol induced change in near surface air temperature with decrease over Southeastern Europe is co-located with the near-surface air temperature positive anomalies of Fig. 1 indicating that the presence of anthropogenic aerosols weakens these temperature anomalies. The temperature changes at $850 \mathrm{hPa}$ are of the same magnitude and they are collocated with those seen at near surface (Fig. 4b) thus denoting that the aerosol induced changes of temperature are similar for the whole lower troposphere. In the middle troposphere (at $500 \mathrm{hPa}$ ) the aerosol induced temperature changes are smaller in magnitude ranging between -0.4 to $+0.3^{\circ} \mathrm{C}$ (Fig. $4 \mathrm{c}$ ). The pat- tern of temperature changes at $500 \mathrm{hPa}$ partially differs from that in the lower troposphere. Specifically, there is still an aerosol induced temperature decrease at the Balkan Peninsula (between $40^{\circ} \mathrm{N}$ and $50^{\circ} \mathrm{N}$ ) and an increase at Northern latitudes but an increase is also revealed over Greece and the Aegean Sea (between $30^{\circ} \mathrm{N}$ and $40^{\circ} \mathrm{N}$ ). This pattern of the aerosol induced changes in air temperature implies a possible dynamical feedback of aerosols on atmospheric circulation as a cause and it is discussed in Sect. 3.3.

The aerosol induced changes in air temperature from near surface to middle troposphere correlate partially in space with the respective aerosol induced changes in total column fractional cloud cover and surface absorbed solar radiation shown in Fig. 5. For example, mind that the decrease in air temperature from near surface to middle troposphere over Southeastern Europe (between $45^{\circ} \mathrm{N}$ and $50^{\circ} \mathrm{N}$ ) is associated with an increase in the total column fractional cloud cover and a decrease in surface absorbed solar radiation. The physical meaning of these correlations is that the 

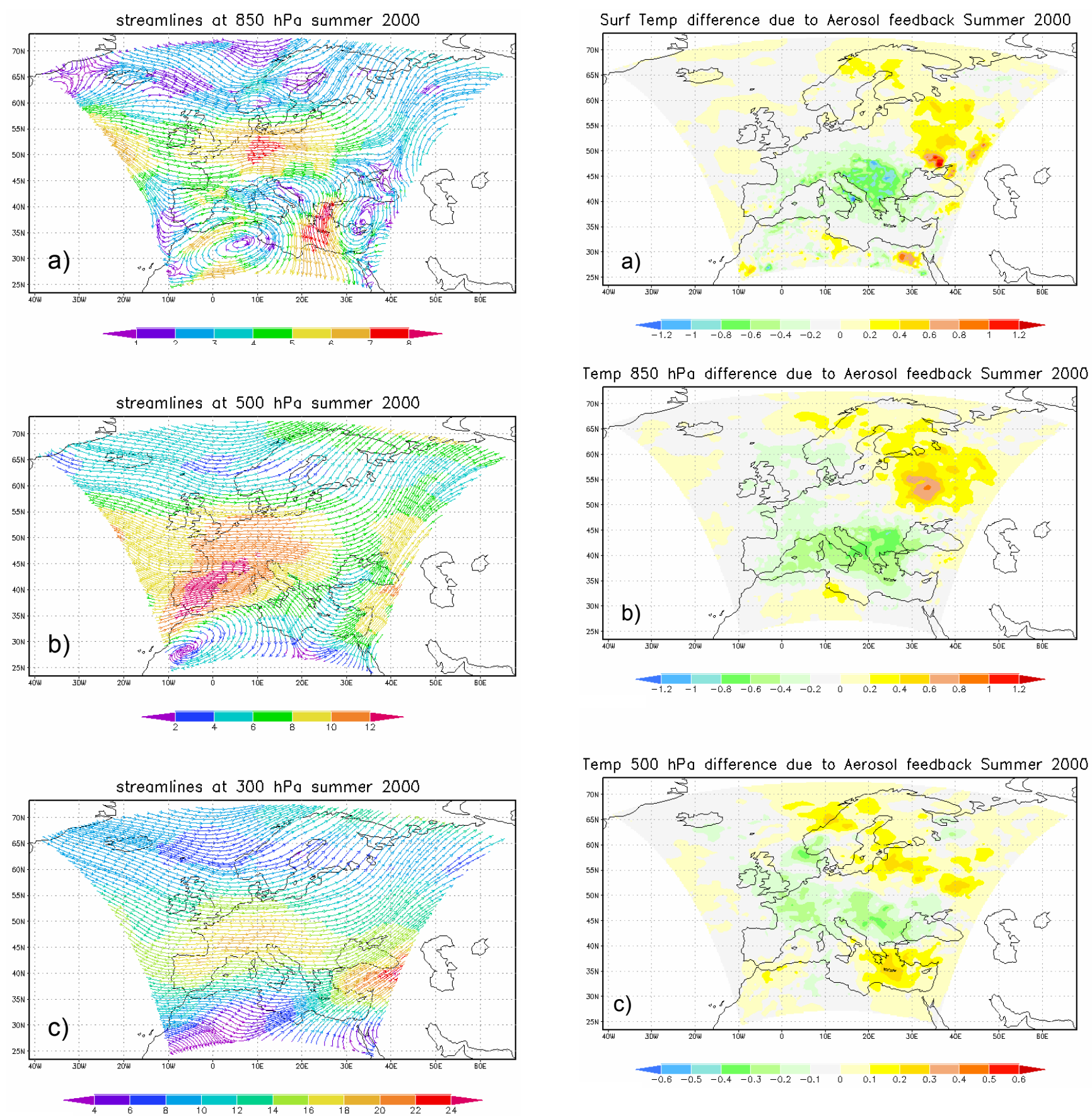

Fig. 3. Average streamlines in summer 2000 for (a) $850 \mathrm{hPa}$, (b) $500 \mathrm{hPa}$ and (c) $300 \mathrm{hPa}$. The color-bars denote the wind speed $(\mathrm{m} / \mathrm{s})$. Mind the different color-scale for the different pressure levels.

changes in near surface air temperature are linked to changes of surface absorbed solar radiation which in turn are associated with changes of total column fractional cloud cover that determines the degree of solar radiation attenuation from clouds. However, the aerosol induced changes of clouds can be largely affected by changes in atmospheric circula-

Fig. 4. Seasonal mean fields in summer for the year 2000 of the difference AFrun-Crun RegCM3/aerosol simulations due to aerosol feedback in (a) near surface air temperature $\left(\operatorname{deg}{ }^{\circ} \mathrm{C}\right)$, (b) air temperature at $850 \mathrm{hPa}\left(\mathrm{deg}{ }^{\circ} \mathrm{C}\right)$ and (c) air temperature at $500 \mathrm{hPa}(\mathrm{deg}$ ${ }^{\circ} \mathrm{C}$ ). Mind the different color-scale for temperature differences at $500 \mathrm{hPa}$.

tion. The discussion in Sect. 3.3, that follows, shows that the aerosol induced increase of the total column fractional cloud cover over Southeastern Europe (between $45^{\circ} \mathrm{N}$ and $50^{\circ} \mathrm{N}$ ) is linked to dynamical feedback of aerosols on atmospheric circulation. 


\subsection{Aerosol induced changes in atmospheric circulation}

In order to attribute the aerosol induced changes in air temperature and cloud cover ovet the Balkan Peninsula to the circulation changes, the aerosol induced changes in the wind fields are investigated. Figure 6 indicates that the inclusion of the feedback of the anthropogenic aerosols in the regional climate simulations induces systematic changes in both the zonal and meridional winds at middle and upper troposphere (500 hPa and $300 \mathrm{hPa}$, respectively). Specifically, Fig. 6a and Fig. $6 \mathrm{c}$ show a decrease of zonal wind at the north in the latitudinal band $45^{\circ} \mathrm{N}-55^{\circ} \mathrm{N}$ and an increase at the south in the latitudinal band $30^{\circ} \mathrm{N}-45^{\circ} \mathrm{N}$ (at both $500 \mathrm{hPa}$ and $300 \mathrm{hPa}$ ). This pattern of aerosol induced changes in zonal wind with respect to the control simulation (with no aerosol feedback) indicates a southward shift of the zonal wind in the middle and upper troposphere. The inspection of zonal winds at $300 \mathrm{hPa}$ (Fig. 6c) and the streamlines at $300 \mathrm{hPa}$ (Fig. 3c) indicates the existence of one branch (European branch) of the subtropical jet stream extending from South France to the Balkan Peninsula (jet exit region) and another branch located over Minor Asia. The aerosol induced southward shift of the zonal winds at $300 \mathrm{hPa}$ (Fig. 6c) denotes an aerosol induced southward shift of the European branch of the subtropical jet stream.

Figures $6 \mathrm{~b}$ and $\mathrm{d}$ illustrate that aerosols induce an increase of the meridional wind in middle and upper troposphere between $30^{\circ} \mathrm{E}$ and $40^{\circ} \mathrm{E}$ at Black Sea, Minor Asia and Ukraine which means strengthening of the Southerly winds. Over the Balkan Peninsula in the middle troposphere (Fig. 6b) that the meridional winds are Northerly, there is no change or very small weakening of the Northerly winds.

The aerosol induced changes in atmospheric circulation at South-eastern and Central-eastern Europe can be more clearly illustrated with meridional cross sections averaged over the longitudinal zone $20^{\circ} \mathrm{E}-30^{\circ} \mathrm{E}$ of the differences in the wind components among the simulations with and without the aerosol feedback (see Fig. 7). In first, the meridional cross section of the air temperature differences (Fig. 7a) illustrates a north-south dipole pattern in the lower troposphere (below about $700 \mathrm{hPa}$ ) with a cooling in Southeastern Europe (in the latitudinal band $30^{\circ} \mathrm{N}-50^{\circ} \mathrm{N}$ ) and slight cooling over Northeastern Europe (in the latitudinal band $55^{\circ} \mathrm{N}-$ $70^{\circ} \mathrm{N}$ ). Above about $700 \mathrm{hPa}$ it should be also noted the slight aerosol induced warming between $30^{\circ} \mathrm{N}$ and $40^{\circ} \mathrm{N}$. The largest temperature difference due to the aerosol feedback is the temperature decrease in the lower troposphere from surface to about $800 \mathrm{hPa}$ in the latitudinal band $40^{\circ} \mathrm{N}-$ $50^{\circ} \mathrm{N}$.

The mean summer meridional cross section of the zonal wind differences shows a dipole pattern with a decrease at the north (in the latitudinal band $45^{\circ} \mathrm{N}-55^{\circ} \mathrm{N}$ ) and an increase at the south (in the latitudinal band $30^{\circ} \mathrm{N}-45^{\circ} \mathrm{N}$ ) in the upper troposphere from about $500 \mathrm{hPa}$ to $200 \mathrm{hPa}$ indicating a southward shift of the zonal wind due to the aerosol feedback
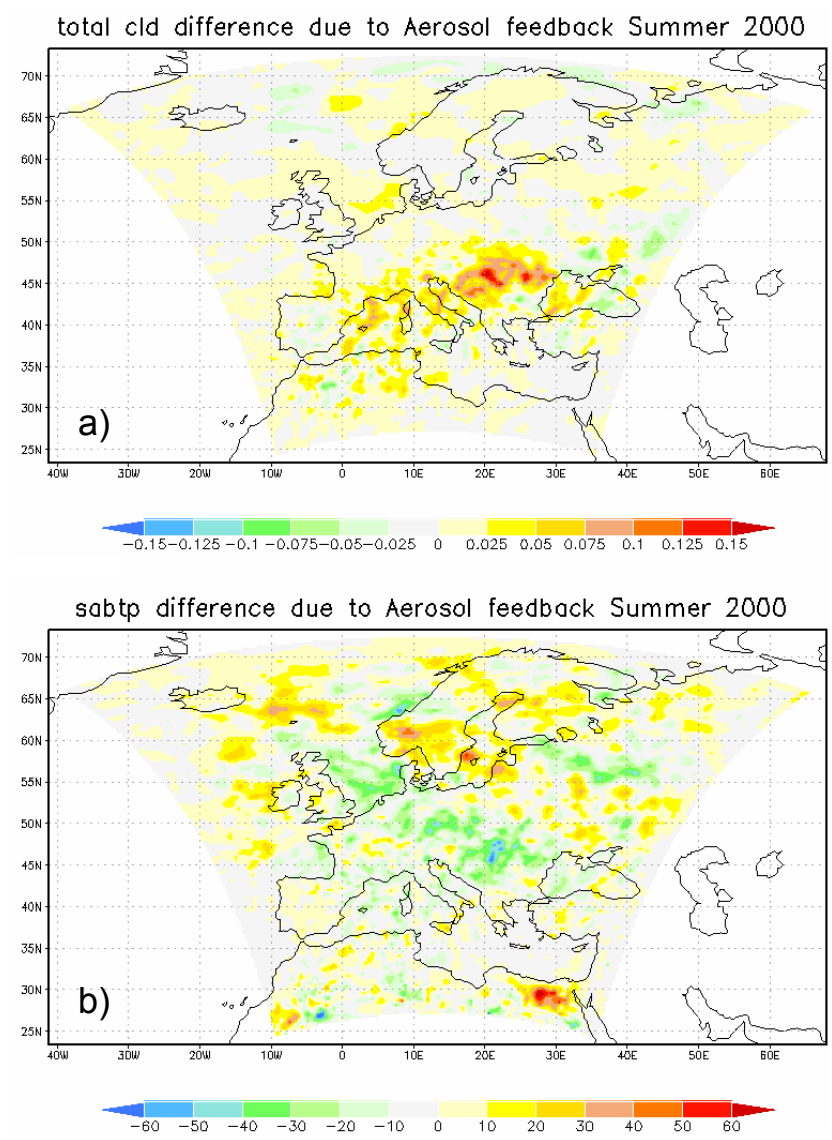

Fig. 5. Seasonal mean fields in summer for the year 2000 of the difference AFrun-Crun RegCM3/aerosol simulations due to aerosol feedback in (a) total column fractional cloud cover (\%) and (b) surface absorbed solar radiation $\left(\mathrm{W} / \mathrm{m}^{2}\right)$. The total column fractional cloud cover denotes the percent coverage by clouds for the total column at each grid point taking into account the fractional cloud cover for each model level.

(Fig. 7b). This denotes the southward shift of the subtropical jet stream as also discussed previously in this section. The meridional cross section of the meridional wind differences (not shown) indicates a weakening of the Northerly winds at south (in the latitudinal band $35^{\circ} \mathrm{N}-45^{\circ} \mathrm{N}$ ) and a weakening of the Southerly winds in the lower troposphere at north (in the latitudinal band $50^{\circ} \mathrm{N}-60^{\circ} \mathrm{N}$ ). This behavior in the change of the meridional wind can be justified by the southward shift of the subtropical jet stream considering that its position determines the northern limit of the Hadley circulation cell.

The mean summer meridional cross section of the vertical wind in the control simulation (shown with black contours in Fig. 7c) indicates downward motion (positive values of vertical wind in $\mathrm{hPa} / \mathrm{s}$ ) at south in the latitudinal band $30^{\circ} \mathrm{N}-45^{\circ} \mathrm{N}$ and small upward motion (negative values of vertical wind in $\mathrm{hPa} / \mathrm{s}$ ) at northern latitudes (in the latitudinal band $55^{\circ} \mathrm{N}-70^{\circ} \mathrm{N}$ ). The inclusion of the aerosols and their 

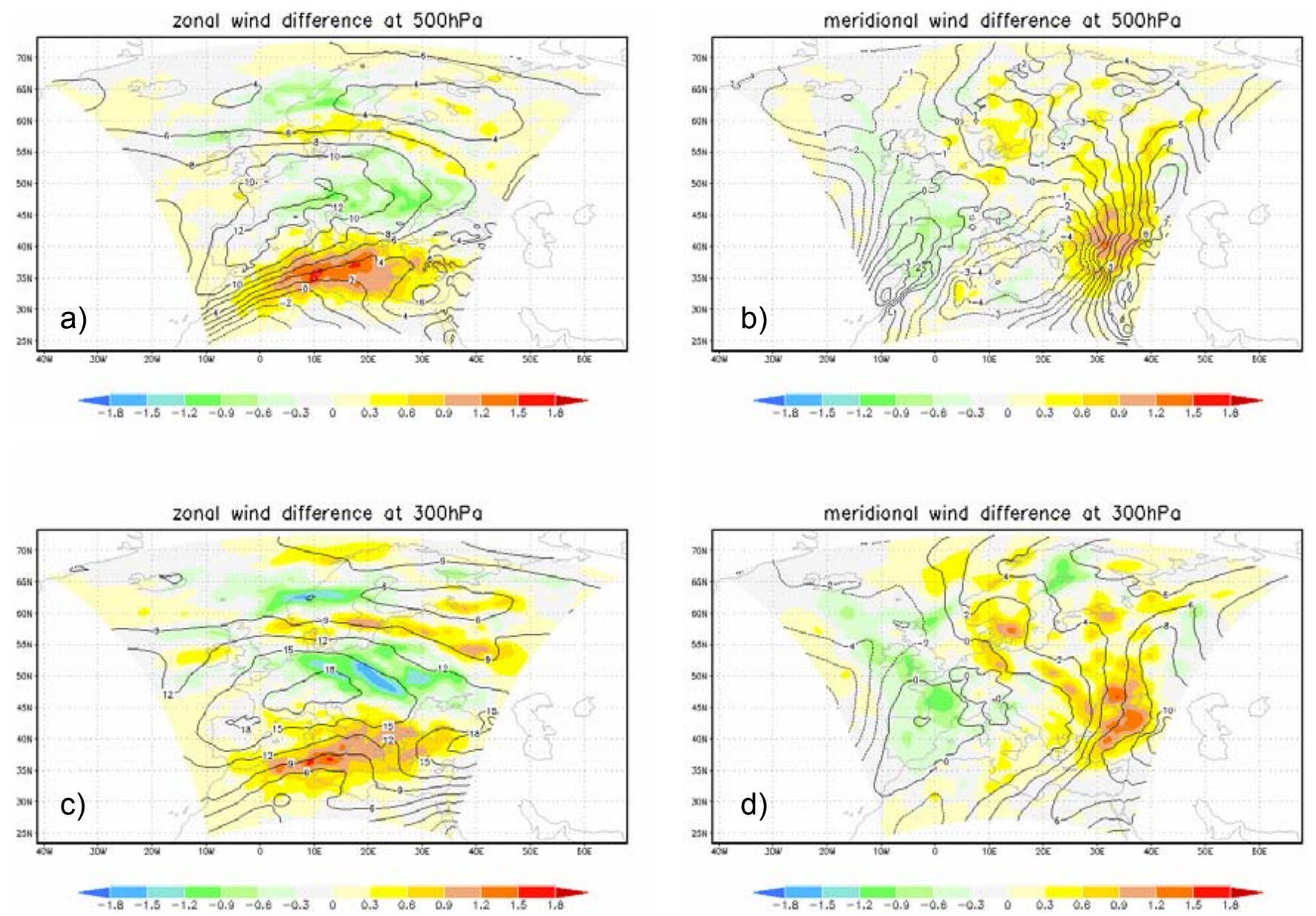

Fig. 6. Seasonal mean fields in summer for the year 2000 of the difference AFrun-Crun RegCM3/aerosol simulations due to aerosol feedback in zonal wind at $500 \mathrm{hPa}$ (a) and $300 \mathrm{hPa}$ (c) and in meridional wind at $500 \mathrm{hPa}$ (b) and $300 \mathrm{hPa}$ (d). The summer seasonal mean fields of zonal and meridional wind in the control simulation (Crun) are superimposed with black contours. The units are in $\mathrm{m} / \mathrm{s}$.

feedback in the simulation causes a southward shift of the downward vertical winds in the latitudinal band $30^{\circ} \mathrm{N}-50^{\circ} \mathrm{N}$ with positive anomalies below $45^{\circ} \mathrm{N}$ (increase of downward motion) and negative anomalies between $45^{\circ} \mathrm{N}$ and $50^{\circ} \mathrm{N}$ (relative decrease of downward motion or relative increase of upward motion). This shift of the downward vertical winds can be associated with the southward shift of the position of the subtropical jet stream. This is justified from the fact that the jet exit region is located over the Balkan Peninsula with downward motions at the southern flank of the jet exit and upward motions at the northern flank. A southward shift of the jet exit due to the aerosol feedback implies a relative increase of upward motion at the northern flank of the jet exit and a relative increase of the downward motion at the southern flank of the jet exit region. Indeed this behavior is in line with the aerosol induced changes of the vertical velocities seen in Fig. 7c.

It should be noted here that the relative increase of upward motion (or relative decrease of the downward motion) in the latitudinal band $45^{\circ} \mathrm{N}-50^{\circ} \mathrm{N}$ (Fig. 7c) coincides with the latitudinal band of the maximum temperature decrease (due to the aerosol feedback) and cloud fraction increase from the surface to about $800 \mathrm{hPa}$ (Fig. 7a and d). The physical explanation is that the southward shift of the subtropical jet causes a southward shift of the jet exit region over the Balkan Peninsula which in turn causes a relative increase of the upward motion at the northern flank of the jet exit region, a relative increase of clouds, less solar radiation absorbed at the surface and hence relative cooler air temperatures in the lower troposphere. Furthermore, from the southward shift of the jet stream can be also justified the aerosol induced relative warming in the latitudinal band between $30^{\circ} \mathrm{N}$ and $40^{\circ} \mathrm{N}$ above about $700 \mathrm{hPa}$ from the middle to upper troposphere as there is a relative increase of the downward motion at the southern flank of the jet exit region and hence of the adiabatic heating of the subsiding air masses.

Mind however that the aerosol induced decrease in air temperature of the lower troposphere extends beyond the 

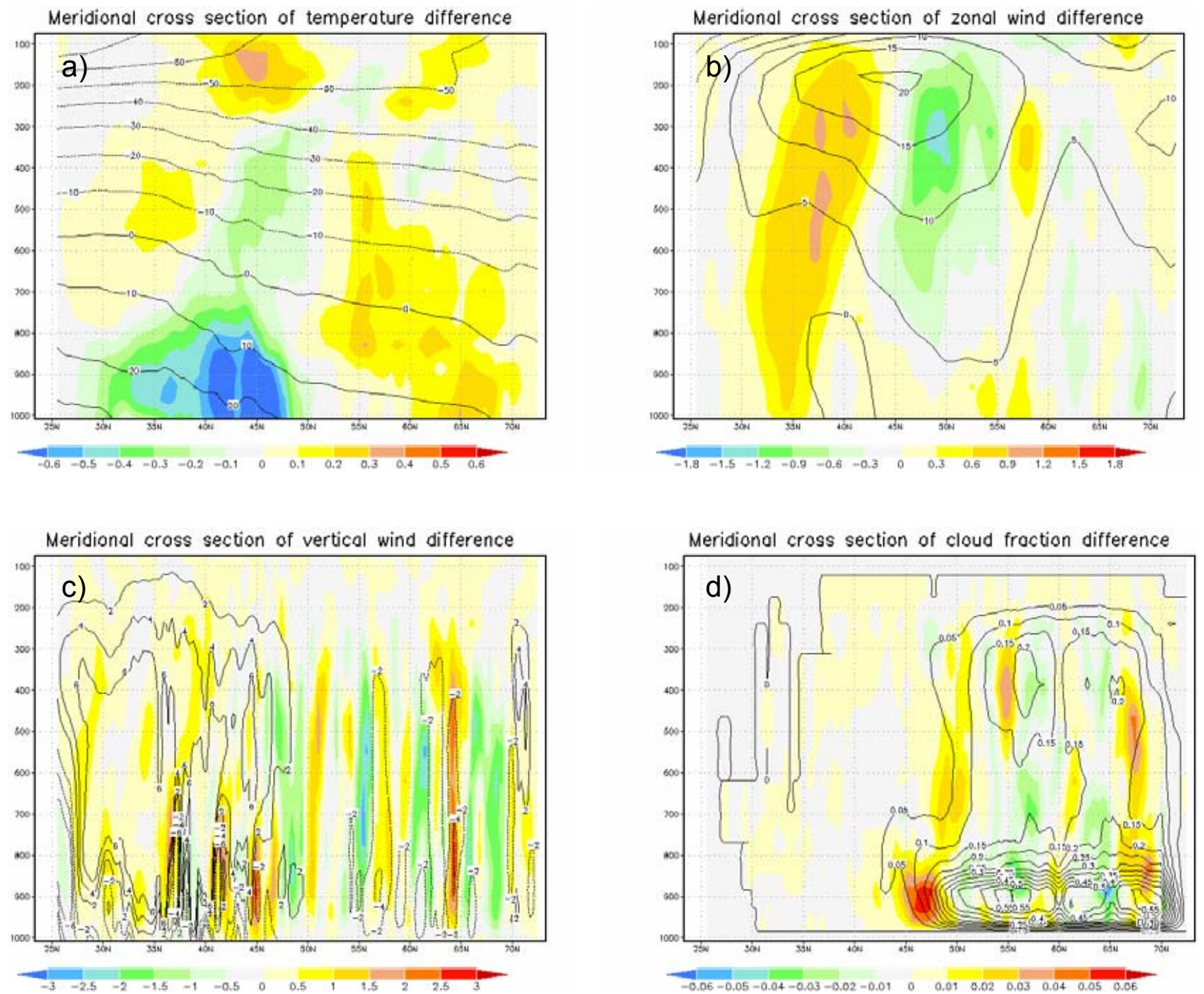

Fig. 7. Mean summer (for the year 2000) meridional cross sections averaged over the longitudinal zone $20^{\circ} \mathrm{E}-30^{\circ} \mathrm{E}$ of the difference AFrunCrun RegCM3/aerosol simulations due to aerosol feedback in (a) air temperature $\left({ }^{\circ} \mathrm{C}\right),(\mathbf{b})$ zonal wind $(\mathrm{m} / \mathrm{s}),(\mathbf{c})$ vertical wind $\left(10^{-5} \mathrm{hPa} / \mathrm{s}\right)$ and (d) cloud fraction (dimensionless). The respective mean summer meridional cross sections of air temperature, zonal, meridional and vertical wind in the control simulation (Crun) are superimposed with black contours.

latitudinal band $45^{\circ} \mathrm{N}-50^{\circ} \mathrm{N}$ to lower latitudes (Fig. 7a). Especially the lower troposphere aerosol induced cooling in the latitudinal band $40^{\circ} \mathrm{N}-45^{\circ}$ is as strong as it is in the latitudinal band $45^{\circ} \mathrm{N}-50^{\circ}$. This behavior cannot be explained by the same mechanism discussed for the latitudinal band $45^{\circ} \mathrm{N}-50^{\circ}$ with the relative increase of upward motion and clouds at the northern flank of the southward shifted jet exit region. However the prevailing northerly flow in the lower troposphere over the Balkan Peninsula (see Fig. 3a) advects the relatively cooler air from the latitudinal band $45^{\circ} \mathrm{N}-50^{\circ} \mathrm{N}$ towards the lower latitudes thus causing a southward extension of the aerosol induced negative temperature changes.
Conclusively, the aerosol induced southward shift of the subtropical jet stream provides a sensible physical explanation for the aerosol induced relative decrease in near surface air temperature over Southeastern Europe and the Balkan Peninsula. The southward shift of the zonal wind and the jet stream due to the negative radiative forcing of the anthropogenic aerosols (combined sulfate and carbonaceous aerosols) in this study is in line with the Intergovernmental Panel on Climate Change (IPCC) models of the fourth assessment report that predict a strengthening and a poleward shift of the tropospheric zonal jets in response to the total positive radiative forcing and global warming (Lorenz and Weaver, 2007). Furthermore this study is also in line with 
a recent modeling study in which it was found that inclusion of sulfate aerosols in climate simulations together with the greenhouse gases causes the future decrease in baroclinicity to get smaller due to the aerosols' cooling effect and the future poleward shift in track density to be partly offset (Fischer-Bruns et al., 2009).

\section{Conclusions}

Two full-year regional climate simulations were performed over Europe for the year 2000 with and without the feedback of anthropogenic aerosols by the regional climate model RegCM3 coupled with a simplified aerosol model. The aerosol model implemented online in RegCM3 includes the $\mathrm{SO}_{2} / \mathrm{SO}_{4}^{=}$system, black carbon and organic carbon considering their hydrophobic and hydrophilic state. In the present work it was investigated the direct shortwave effect of anthropogenic aerosols on the near surface temperature over Southeastern Europe and the atmospheric circulation during summer 2000. The summer of the year 2000 was characterized by high temperature climatic anomalies in Southeastern Europe while severe heat-wave and droughts affected many countries in the Balkans.

The derived mean summer surface radiative forcing associated with the anthropogenic aerosols was negative throughout the European domain with the more negative sRF values located in Central and Central-eastern Europe where the highest anthropogenic aerosol loading is attained. The aerosol induced changes in near surface air temperature and middle troposphere were not correlated with the respective pattern of the surface radiative forcing implying the complexity and the non-linearity of the mechanisms linking the aerosol radiative forcing with the induced atmospheric changes.

A basic pattern of the aerosol induced changes in air temperature at the lower troposphere was a decrease over Southeastern Europe and the Balkan Peninsula thus weakening the pattern of the climatic temperature anomalies of summer 2000. The maximum temperature difference due to the aerosol feedback is the temperature decrease (up to about $1.2^{\circ} \mathrm{C}$ ) at near surface over Southeastern Europe. The decrease in air temperature from near surface to middle troposphere over Southeastern Europe (between $45^{\circ} \mathrm{N}$ and $50^{\circ} \mathrm{N}$ ) is associated with an increase in the total column fractional cloud cover and a decrease in surface absorbed solar radiation. The pattern of the aerosol induced changes in air temperature as well as the correlation of the aerosol induced changes between the near surface air temperature and the total column fractional cloud cover indicates a possible dynamical feedback of aerosols on atmospheric circulation.

Indeed a combined inspection of the aerosol induced changes in the wind components and the circulation indicates a southward shift of the subtropical jet stream. playing a dominant role for the decrease in near surface air temper- ature over Southeastern Europe and the Balkan Peninsula. Specifically, the southward shift of the jet exit region over the Balkan Peninsula causes a relative increase of the upward motion at the northern flank of the jet exit region, a relative increase of clouds, less solar radiation absorbed at the surface and hence relative cooler air temperatures in the lower troposphere between $45^{\circ} \mathrm{N}$ and $50^{\circ} \mathrm{N}$. The lower troposphere aerosol induced cooling in the latitudinal band $35^{\circ} \mathrm{N}-45^{\circ} \mathrm{N}$ over the Balkan Peninsula can be justified from the prevailing northerly flow advecting the relatively cooler air from the latitudinal band $45^{\circ} \mathrm{N}-50^{\circ} \mathrm{N}$ towards the lower latitudes thus causing a southward extension of the aerosol induced negative temperature changes. Furthermore, the southward shift of the jet stream explains the aerosol induced relative warming in the latitudinal band between $30^{\circ} \mathrm{N}$ and $40^{\circ} \mathrm{N}$ from the middle to upper troposphere as there is a relative increase of the downward motion at the southern flank of the jet exit region and hence of the adiabatic heating of the subsiding air masses. The present regional climate modeling study indicates the important role of anthropogenic aerosols for the regional climate and their dynamical feedback on atmospheric circulation.

The short length of the simulations presented in the study for a specific year is not sufficiently long to establish a climatic signal of the aerosol radiative forcing, but this study focuses on the short-term signals for a relatively warm summer in the Balkan Peninsula. An analysis of a 12-years simulation from 1996 to 2007 with and without the aerosol feedback is in progress in order to establish a longer-term climate signal of the anthropogenic aerosols in Europe.

Acknowledgements. The author would like to thank F. Solmon (Laboratoire d'Aérologie, Toulouse, France), A. S. Zakey and X. Bi (Abdus Salam International Centre for Theoretical Physics, Trieste, Italy) for their support on issues related to RegCM3/aerosol simulations.

Support by a research and education PYTHAGORAS II grant co-funded by the Greek Ministry of Education (25\%) and the European Social Fund (75\%) is acknowledged. NCEP Reanalysis derived data provided by the NOAA/OAR/ESRL PSD, Boulder, Colorado, USA, from their Web site at http://www.cdc.noaa.gov/.

Topical Editor F. D' Andrea thanks two anonymous referees for their help in evaluating this paper.

\section{References}

Cooke, W. F., Ramaswamy, V., and Kasibhatla, P.: A general circulation model study of the global carbonaceous aerosol distribution, J. Geophys. Res., 107(D16), 4279, doi:10.1029/2001JD001274, 2002.

Chung, S. H. and Seinfeld, J. H.: Global distribution and climate forcing of carbonaceous aerosols, J. Geophys. Res., 107, D194407, doi:10.1029/2001JD001397, 2002.

Dickinson, R., Henderson-Sellers, A., and Kennedy, P. J.: Biosphere-Atmosphere Transfer Scheme, BATS: version1E as coupled to the NCAR Community Climate Model. NCAR Tech- 
nical Note No NCAR/TN-387+STR, Boulder, CO, 72 pp, available from the National Center for Atmospheric Research, P.O. Box 3000, Boulder, CO 80307, 1993.

Ekman, A. M. L. and Rodhe, H.: Regional temperature response due to indirect sulfate aerosol forcing: impact of model resolution, Clim. Dynam., 21, 1-10, 2003.

Fischer-Bruns, I., Banse, D. F., and Feichter, J.: Future impact of anthropogenic sulfate aerosol on North Atlantic climate, Clim. Dynam., 32, 511-524, doi:10.1007/s00382-008-0458-7, 2009.

Fritsch, J. M. and Chappell, C. F.: Numerical prediction of convectively driven mesoscale pressure systems. part i: Convective parameterization, J. Atmos. Sci., 37, 1722-1733, 1980.

Ghan, S. J. and Schwartz, S. E.: Aerosol properties and processes: A Path from Field and Laboratory Measurements to Global Climate Models, Bulletin of American Meteorological Society, doi:10.1175 /BAMS-88-7-1059, 1059-1083, 2007.

Giorgi, F., Bi, X., and Qian, Y.: Direct radiative forcing and regional climatic effects of anthropogenic aerosols over east Asia: a regional coupled climate-chemistry/aerosol model study, J. Geophys. Res., 107, d16, doi:10.1029/2001JD001274, 2002.

Giorgi, F., Bi, X., and Qian, Y.: Indirect versus direct effects of anthropogenic sulfate on the climate of east Asia as simulated with a regional coupled climate-chemistry/aerosol model, Clim. Change, 58, 345-376, 2003.

Giorgi, F., Pal, J. S., Bi, X., Sloan, L., Elguindi, N., and Solmon, F.: Introduction to the TAC special issue: The RegCNET network, Theor. Appl. Climatol., 86, 1-4, doi:10.1007/s00704-005-0199z, 2006.

Grell, G. A.: Prognostic evaluation of assumptions used by cumulus parametrizations, Mon. Weather Rev., 121, 764-787, 1993.

Grell, G. A., Dudhia, J., and Stauer, D. R.: A description of the fifthgeneration penn state/ncar mesoscale model (mm5), Technical report NCAR/TN-398+STR, National Center for Atmospheric Research, 1994.

Hansen, J., Sato, M., and Ruedy, R.: Radiative forcing and climate response, J. Geophys. Res., 102(D6), 6831-6864, 1997.

IPCC, Climate change 2001: The scientific basis, Third Assessment Report of the IPCC (Intergovernmental Panel on Climate Change), edited by: Houghton, J. T., Ding, Y., Griggs, D. J., Noguer, M., Van der Linden, P. J., Dai, X., Maskell, K., and Johnson, C. A., Cambridge University Press, Cambridge, UK, 881 pp., 2001.

IPCC, Climate Change 2007: The Physical Science Basis, Contribution of Working Group I to the Fourth Assessment Report of the Intergovernmental Panel on Climate Change, edited by: Solomon, S., Qin, D., Manning, M., Chen, Z., Marquis, M., Averyt, K. B., Tignor, M., and Miller, H. L., Cambridge University Press, Cambridge, United Kingdom and New York, NY, USA, 996 pp., 2007.

Jacobson, M. Z.: Strong radiative heating due to the mixing state of black carbon in atmospheric aerosols, Nature, 409, 695-697, 2001.

Johnson, B. T., Shine, K. P., and Forster, P. M.: The semidirect aerosol effect: Impact of absorbing aerosols on marine stratocumulus, Q. J. Roy. Meteorol. Soc., 130, 1407-1422, doi:10.1256/qj.03.61, 2004.

Kalnay, E., Kanamitsu, M., Kistler, R., Collins, W., Deaven, D., Gandin, L., Iredell, M., Saha, S., White, G., Woollen, J., Zhu, Y., Chelliah, M., Ebisuzaki, W., Higgins, W., Janowiak, J., Mo,
K.C., Ropelewski, C., Wang, J., Leetmaa, A., Reynolds, R., Jenne, R., and Joseph, D.: The NCEP/NCAR 40-year reanalysis project, B. Am. Meteorol. Soc., 77, 437-470, 1996.

Kanamitsu, M., Ebisuzaki, W., Woollen, J., Yang, S. K., Hnilo, J. J., Fiorino, M., and Potter, G. L.: NCEP-DOE AMIP-II Reanalysis (R-2), B. Am. Meteorol. Soc., 83, 1631-1643, 2002.

Kiehl, J. T., Hack, J. J., Bonan, G. B., Boville, B. A., Breigleb, B. P., Williamson, D., and Rasch, P.: Description of the ncar community climate model (ccm3), Tech. Rep. NCAR/TN-420+STR, National Center for Atmospheric Research, 1996.

Kim, M. K., Lau, W. K. M., Kim, K. M., and Lee, W. S.: A GCM study of effects of radiative forcing of sulfate aerosol on large scale circulation and rainfall in East Asia during boreal spring, Geophys. Res. Lett., 34, L24701, doi:10.1029/2007GL031683, 2007.

Konare, A., Zakey, A. S., Solmon, F., Giorgi, F., Rauscher, S., Ibrah, S., and Bi, X.: A regional climate modeling study of the effect of desert dust on the West African monsoon, J. Geophys. Res., 113, D12206, doi:10.1029/2007JD009322, 2008.

Li, F., Vogelmann, A. A., and Ramanathan, V.: Saharan dust aerosol radiative forcing measured from Space, J. Climate, 17, 25582571, 2004.

Lohmann, U. and Feichter, J.: Can the direct and semi-direct aerosol effect compete with the indirect effect on a global scale?, Geophys. Res. Lett., 28(1), 159-161, 2001.

Lohmann, U. and Feichter, J.: Global indirect aerosol effects: a review, Atmos. Chem. Phys., 5, 715-737, 2005, http://www.atmos-chem-phys.net/5/715/2005/.

Lorenz, D. J. and DeWeaver, E. T.: Tropopause height and zonal wind response to global warming in the IPCC scenario integrations, J. Geophys. Res., 112, D10119, doi:10.1029/2006JD008087, 2007.

Menon, S., Hansen, J., Nazarenko, L., and Luo, Y.: Climate Effects of Black Carbon Aerosols in China and India, Science, 297, 2250-2252, 2002.

Norris, J. R. and Wild, M.: Trends in aerosol radiative effects over Europe inferred from observed cloud cover, solar "dimming” and solar "brightening”, J. Geophys. Res., 112, D08214, doi:10.1029/2006JD007794, 2007.

Pal, J. S., Small, E. E., and Eltahir, E. A. B.: Simulation of regionalscale water and energy budgets:Representation of subgrid cloud and precipitation processes within RegCM, J. Geophys. Res., 105(D24), 29579-29594, 2000.

Pal, J. S., Giorgi, F., Bi, X., Elguindi, N., Solomon, F., Gao, X., Rauscher, S. A., Francisco, R., Zakey, A., Winter, J., Ashfaq, M., Syed, F. S., Bell, J. L., Diffenbaugh, N. S., Karmacharya, J., Konare, A., Martinez, D., da Rocha, R. P., Sloan, L. C., and Steiner, A. L.: Regional climate modeling for the developing world: The ICTP RegCM3 and RegCNET, B. Am. Meteorol. Soc., 88, 1395-1409, 2007.

Qian, Y., Giorgi, F., and Huang, Y.: Regional simulation of anthropogenic sulfur over east asia and its sensitivity to model parameters, Tellus, 53, 171-191, 2001.

Qian, Y., Leung, L. R., Ghan, S. J., and Giorgi, F.: Regional climate effects of aerosols over China: modeling and observations, Tellus, 55B, 914-934, 2003.

Ramanathan, V., Crutzen, P. J., Kiehl, J. T., and Rosenfeld, D.: Aerosols, Climate, and the hydrological cycle, Science, 294, 2119-2124, 2001. 
Ramanathan, V. and Feng, Y.: Air pollution, greenhouse gases and climate change: Global and regional perspectives, Atmos. Environ., 43, 37-50, 2009.

Reddy, M. S. and Boucher, O.: A study of the global cycle of carbonaceous aerosols in the LMDZT general circulation model, J. Geophys. Res., 109, D14202, doi:10.1029/2003JD004048, 2004.

Ruckstuhl, C., Philipona, R., Behrens, K., Coen, M. C., Dürr, B., Heimo, A., Mätzler, C., Nyeki, S., Ohmura, A., Vuilleumier, L., Weller, M., Wehrli, C., and Zelenka, A.: Aerosol and cloud effects on solar brightening and the recent rapid warming, Geophys. Res. Lett., 35, L12708, doi:10.1029/2008GL034228, 2008.

Solmon, F., Giorgi, F., and Liousse, C.: Aerosol modelling for regional climate studies: application to anthropogenic particles and evaluation over a European/African domain, Tellus, 58B, 51-72, doi:10.1111/j.1600-0889.2005.00155.x, 2006.

Solmon, F., Mallet, M., Elguindi, N., Giorgi, F., Zakey, A., and Konare, A.: Dust aerosol impact on regional precipitation over western Africa, mechanisms and sensitivity to absorption properties, Geophys. Res. Lett., 35, L24705, doi:10.1029/2008GL035900, 2008.

Stanhill, G. and Cohen, S.: Global dimming: A review of the evidence for a widespread and significant reduction in global radiation with discussion of its probable causes and possible agricultural consequences, Agric. For. Meteorol., 107, 255-278, 2001.
Sud, Y. C., Lau, W. K. M., Wilcox, E., Walker, G. K., Liu, X. H., Nenes, A., Lee, D., Kim, K. M., Zhou, Y., and Bhattacharjee, P. S.: Sensitivity of Boreal-Summer Circulation and Precipitation to Atmospheric Aerosols in Selected Regions - Part 1: Africa and India, Ann. Geophys., in press, 2009.

Wild, M., Ohmura, A., and Makowski, K.: Impact of global dimming and brightening on global warming, Geophys. Res. Lett., 34, L04702, doi:10.1029/2006GL028031, 2007.

Zakey, A. S., Solmon, F., and Giorgi, F.: Implementation and testing of a desert dust module in a regional climate model, Atmos. Chem. Phys., 6, 4687-4704, 2006, http://www.atmos-chem-phys.net/6/4687/2006/.

Zakey, A. S., Giorgi, F., and Bi, X.: Modeling of sea salt in a regional climate model: Fluxes and radiative forcing, J. Geophys. Res., 113, D14221, doi:10.1029/2007JD009209, 2008.

Zeng, X., Zhao, M., and Dickinson, R. E.: Intercomparison of bulk aerodynamic algorithms for the computation of sea surface fluxes using toga coare and tao data, J. Climate, 11 2628-2644, 1998.

Zhang, D. F., Zakey, A. S., Gao, X. J., Giorgi, F., and Solmon, F.: Simulation of dust aerosol and its regional feedbacks over East Asia using a regional climate model, Atmos. Chem. Phys., 9, 1095-1110, 2009,

http://www.atmos-chem-phys.net/9/1095/2009/. 